\title{
SEJARAH PERKEBUNAN DAN DAMPAKNYA BAGI PERKEMBANGAN MASYARAKAT DI ONDERAFDEELING BANJOEASIN EN KOEBOESTREKKEN, KERESIDENAN PALEMBANG, 1900-1942
}

\author{
Zusneli Zubir \\ Balai Pelestarian Nilai Budaya (BPNB) Padang \\ Jalan Raya Belimbing No 16A Kuranji Padang \\ E-mail: zusneli_z@yahoo.co.id
}

\begin{abstract}
The purposeandobject ofthis paperisarelevancebetween the existence oflarge estates, Onderneming Europeandits impact on societyin Onderafdeeling Banjoeasinen Koeboestrekenthe colonial periodin 1900-1942. The method usedin this studyis the historical method to reconstruct the history of the plantationand the implications forthe development of society in Onderafdeeling Banjoeasinen Koeboestrekken. Data collection techniques use drefersto the first stage in the history ofthe process of heuristic methods, finding and collecting historical sources. Data analysis techniques with regard to the second stage, third and fourth in the history covering methods of source criticism, and historiography interpretation. Based on the research results and conclusions, the opening rubber plantations in the colonial period Onder afdeeling Banjoeasinen Koeboe strekken highly correlated with the natural conditions of this area and also the political changeskonial, open the door. There are two big companies that invest heavily large plantations of rubber namely, first, Rubber Ondernemingen Melaniain 1909 the plantingand effort trubber massively from the east end of Marga Pangkalan Balai to the west end Marga Gasing and centered in Musi Landas. Secondly, plantation Oud Wassenaar, N.V. Oliepalmenen rubber Mijnsprawling in the gutter are as ranging northern Batang Hari Leko, Marga Rantau Bayur, toits northern Marga Suak Tape, Marga Betung and Tebenan area. The relevance of the opening of a large estate with acommunity in Onder afdeeling Banjoeasinen Koeboe strekkenseenin some ways. First, the change in the position of the local elite, the Pasirah, Kerio, others Marga council officials. Secondly, helped create the "repair" the public infrastructure facilities and infrastructures there. Third, encourage the development ofeconomic activity and providea tremendous impact in the dusun-dusun marga's. Fourth, many builders connecting road for the purposes of transportation of rubber has abroad and profound impacton the pattern of a traditional society, not only for the Malays Banjoeasin, but also to aspects of the life of the Kubu's Banjoeasin. They began the gradual assimilation are creating Kubu's Banjoeasin with Malay Banjoeasin due to changes in the orientation of his thinking because it began opening their areas of influence of the outside world.
\end{abstract}

Keywords: Socio-economic history, Plantation Large,Malay Banjoeasin, Kubu Banjoeasin

\begin{abstract}
Abstrak
Tujuan dan objek tulisan ini adalah suatu relevansi antara keberadaan perkebunan besar, onderneming Eropa dan dampaknya bagi masyarakat di Onderafdeeling Banjoeasin en Koeboestreken pada masa kolonial tahun 1900-1942. Metode yang digunakan dalam penelitian ini adalah metode sejarah untuk merekonstruksi mengenai sejarah perkebunan dan dampaknya bagi perkembangan masyarakatdi Onderafdeeling Banjoeasin en Koeboestrekken. Teknik pengumpulan data yang digunakan mengacu dengan tahap pertama dalam metode sejarah yaitu proses heuristik, mencari dan mengumpulkan sumber-sumber sejarah. Teknik analisis data berkenaan dengan tahap kedua, ketiga dan keempat dalam metode sejarah yang meliputi kritik sumber, interpretasi dan historiografi. Berdasarkan hasil
\end{abstract}


penelitian dan kesimpulan, maka pembukaan perkebunan karet masa kolonial di Onderafdeeling Banjoeasin en Koeboestrekken sangat berhubungan dengan keadaan alam daerah ini dan juga adanya perubahan politik konial, open the door. Ada dua perusahaan besar yang melakukan investasi besarbesaran perkebunan besar karet yakni, pertama, Rubber Ondernemingen Melania pada tahun 1909 yang melakukan penanaman dan usaha karet secara besar-besaran mulai dari ujung timur Marga Pangkalan Balai sampai ke ujung barat Marga Gasing dan berpusat di Musi Landas. Kedua, perkebunan Oud Wassenaar, N.V. Oliepalmen en rubber Mijn yang membentang luas di daerah-daerah talang mulai bagian utara Batang Hari Leko, Marga Rantau Bayur, ke utaranya Marga Suak Tape, Marga Betung dan daerah Tebenan. Relevansi pembukaan perkebunan besar dengan masyarakat di Onderafdeeling Banjoeasin en Koeboestrekken terlihat dalam beberapa hal. Pertama, adanya perubahan posisi elit lokal, para pasirah, kerio, pejabat dewan marga lainnya. Kedua, turut menciptakan "perbaikan" sarana dan prasana infrastruktur masyarakat di sana. Ketiga, mendorong berkembangnya kegiatan ekonomi dan memberikan dampak yang luar biasa di dusun-dusun marga. Keempat, banyaknya pembangun jalan penghubung untuk keperluan transportasi hasil karetnya memiliki dampak yang luas dan mendalam terhadap pola masyarakat tradisional, tidak saja bagi orang Melayu Banyuasin, tetapi juga bagi segi-segi kehidupan orang Kubu. Mereka mulai memciptakan asimilasi bertahap orang Kubu dengan penduduk Melayu akibat adanya perubahan orientasi pemikirannya karena mulai terbukanya daerah-daerah mereka dari pengaruh dunia luar.

Kata Kunci: Sejarah Sosial-Ekonomi, Perkebunan Besar, Melayu Banyuasin, Kubu Banyuasin

\section{A. PENDAHULUAN}

Pada masa kolonial Onderafdeeling Banjoeasin en Koeboestreken, sekarang Kabupaten Banyuasin, merupakan kabupaten terdekat dan berbatasan langsung pada bagian utara dengan Kota Palembang, dulu beribukota dan kedudukan kontroleur berada di Talang Betoetoe. (Memorie van Overgave, 1918 No. 13) Onderafdeeling Banjoe Asin en Koeboestreken termasuk dalam Afdeelingen Palembangsche Benedenlanden, Palembang daerah-daerah dataran rendah, yang beribukota di Palembang, pada masa Kesultanan Palembang, termasuk ke dalam "daerah sikap", di samping Belida dan Pegagan, sama seperti sistem pemerintahan di daerah uluan, wilayah ini tidak mempunyai pemerintahan sendiri, tetapi diperintah langsung oleh pegawai yang ditunjuk rajaPalembang dibawah kendali seorang jenang. (Hambali, 1991/1992: 20) Mereka dibebaskan dari kewajiban membayar pajak pada umumnya karena mereka adalah kepercayaan dari raja.

Menariknya, ketika pemerintah kolonial Belanda, dengan politik liberalismenya, selama kurun 1870-1900, serta terlebih pada masa politik open the door policy,politik pintu terbuka, yang dibuka sejaktahun 1930, dalam membuka kran swastanisasi perkebunan seluas-luasnya, daerah ini muncul sebagai daerah perkebunan besar sebagai dampak dari kebijakan politik ekonomi kolonial tersebut. Dalam politik seperti itu, menurut Day (2009: 68), Pemerintah Kolonial Belanda mengambil sikap laisser faire di mana peran dominan pemerintah dalam perekonomian, termasuk usaha perkebunan, mengalami penurunan peranannya.Onderafdeeling Banjoeasin en Koeboestreken merupakan wilayah yang juga terkena dampak dari pengembangan besar-besaran perkebunan swasta yang dimiliki oleh orang Eropa. Menurut O'Malley (1988: 
197), perkebunan merupakan aspek terpenting dalam pemandangan ekonomi di Indonesia pada masa kolonial. Usaha perkebunan yang semula diadakan di Jawa itu, menjelang akhir abad ke19 mulai dikembangkan dan meluas di luar pulau Jawa, khususnya Sumatera. Akibat pemberlakuan ini hutan-hutan belantara di daerah Onderafdeeling Banjoeasin en Koeboestreken, Keresidenan Palembang dibuka untuk dijadikan daerah perkebunan milik perusahaan Eropa.

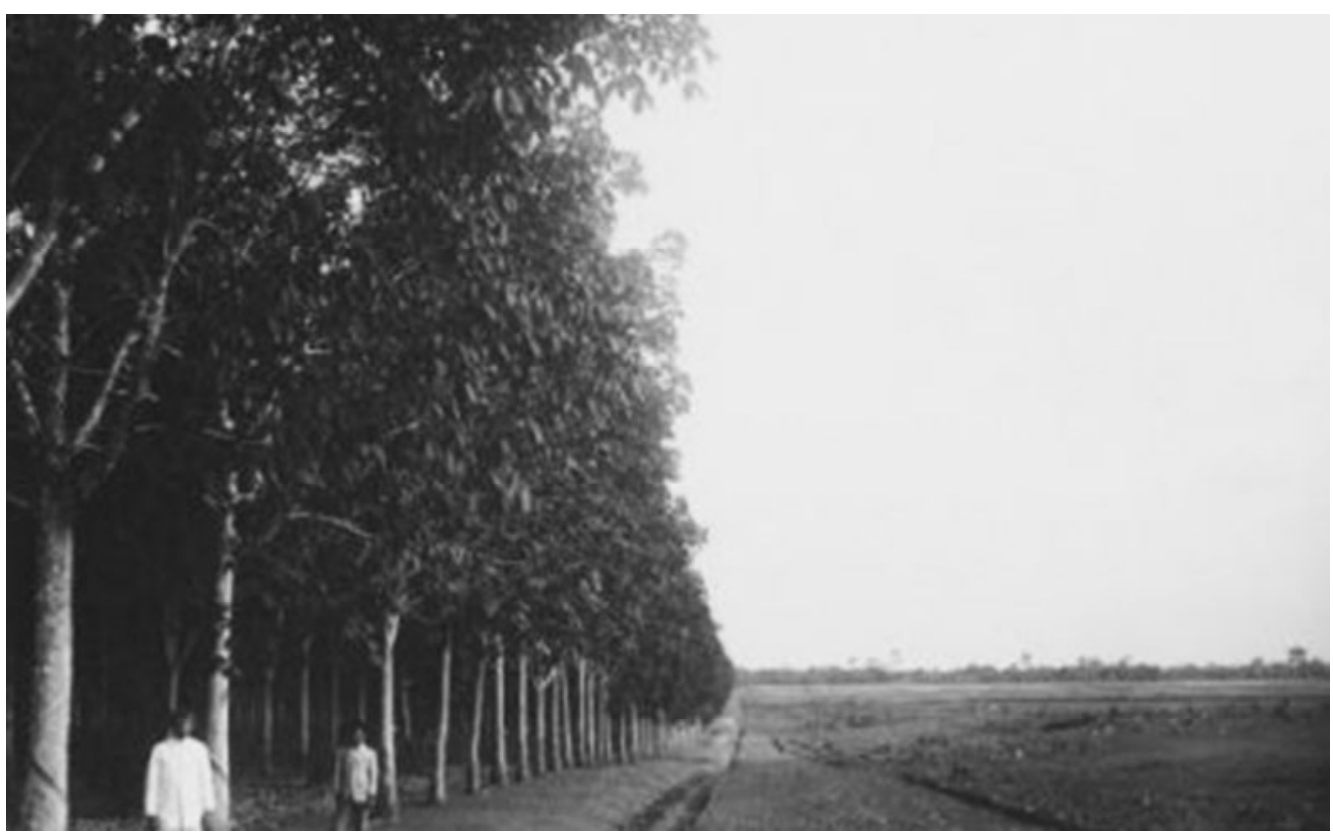

Gambar 1. Area Perkebunan Karet Tebenan

di Onderafdeeling Banjoeasin en Koeboestrekken, 1938. (Sumber: kitlv.nl)

Menurut Hoedt (1929: 202), wilayah perkebunan, cultuurgebeid di Onderafdeeling Banjoeasin en Koeboestreken, tanahnya sangat cocok untuk tanaman karet dan kelapa sawit yang memiliki prospek sangat menguntungkan dalam pasaran dunia. Karena itu, Pemerintah Kolonial Belanda begitu antusias dalam mendukung golongan pengusaha swasta untuk membuka perkebunan dan menanamkan modalnya di daerah Onderafdeeling Banjoeasin en Koeboestreken. Pada 1906 dikeluarkan Staatblad nomor 93 yang memuat peraturan pemerintah kolonial tentang penyewaan lahan di Keresidenan Palembang yang memberi hak menyewa lahan kepada dua pihak yaitu pertama, orang Belanda, dan kedua, orang Eropa lain, yang mempunyai kegiatan usaha serta perusahaan dagang yang didirikan di Hindia Belanda, termasuk perkebunan. Akibatnya, di Onderafdeeling Banjoeasin en Koeboestreken, termasuk juga di wilayah Keresidenan Palembang lainya muncul banyak tanah sewa onderneming yang disebut tanah erfpacht. Dalam catatan Wellan (1932: 305) ada sebanyak 307 tanah erfpacht dengan jumlah luasnya mencakup 450.320 ha di Keresidenan Palembang, dengan sebanyak 65 tanah erfpacht dengan luas 47.660 ada di wilayah Onderafdeeling Banjoeasin en Koeboestreken.

Pembukaan perkebunan besar, onderneming di Onderafdeeling Banjoeasin en Koeboestreken ini sangat luas, mencakup hampir seluruh wilayah-wilayah marganya yang kemudian bersentuhan baik secara langsung maupun tidak langsung, dengan usaha perkebunan karet dan kelapa sawit ini. Persentuhan dengan dunia baru yang ditularkan lewat perkebunan 
besar Eropa ini memiliki relevansi yang sangat kuat, karena bagaimana pun perkebunan besar Eropa adalah model yang kemudian melahirkan modernitas, sekaligus kepingan bagiannya yang disebut kapitalisme. Menurut Zed (2003: 68) perkebunan besar, onderneming Eropa ini merupakan bagian dari kemunculan industri Barat yang mendorong lahirnya komersialisasi pertanian besar-besaran, yang sebelumnya hanya bersifat tradisional di Keresidenan Palembang, termasuk di Onderafdeeling Banjoeasin en Koeboestreken.

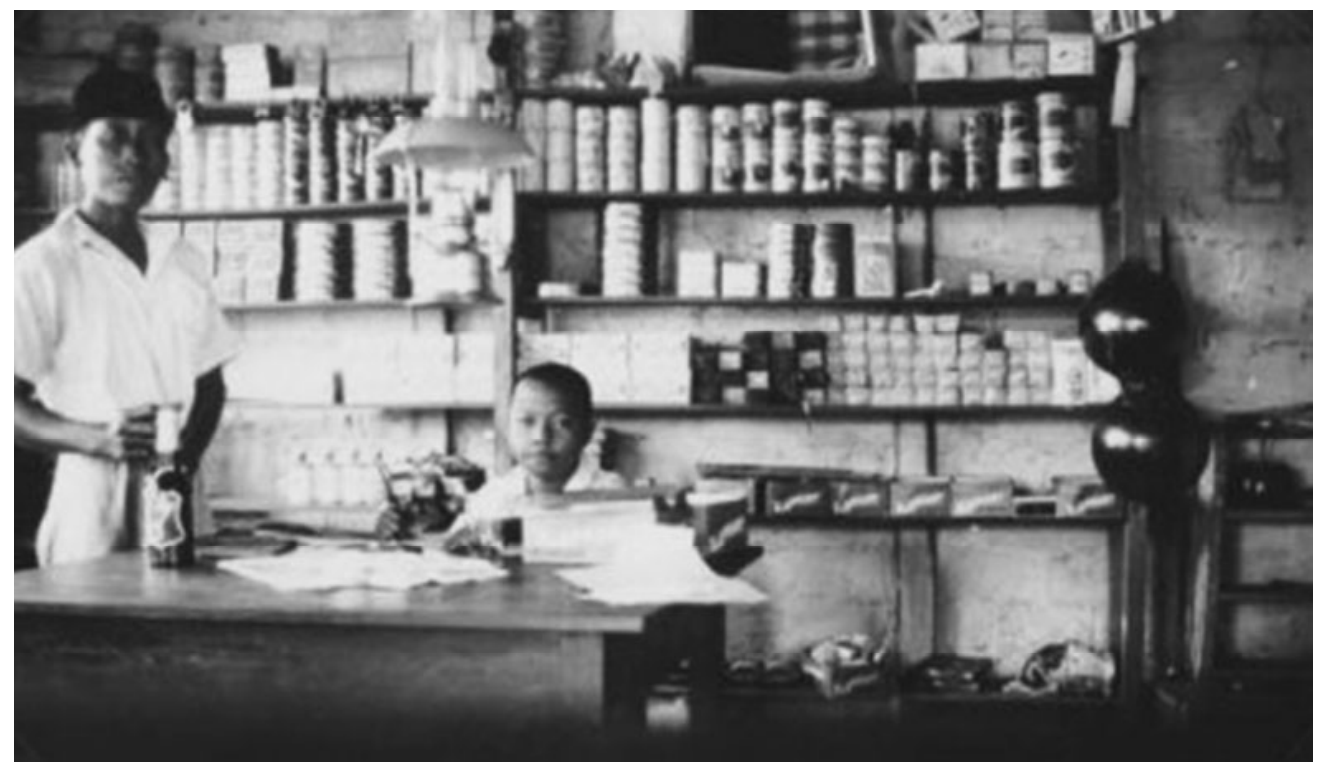

Gambar 2. Toko kelontong dalam area Perkebunan Tebenan di Onderafdeeling Banjoeasin en Koeboestrekken. Berbagai barang dagangan Eropa mulai dikenalkan pada masyarakat pribumi. (Sumber: kitlv.nl)

Pada akhirnya, kehadiran perusahaan Barat dalam dunia perkebunan telah menciptakan tatanan perdagangan lokal yang sangat komplek, pembangunan insfrastruktur sarana dan prasarana penunjang industri perkebunan Barat modern yang menghubungkan dunia tradisional masyarakat lokal ke dunia "luarnya" yang kemudian jauh lebih kompleks dan dinamis, serta pengenalan ekonomi jenis baru yang dulu jarang mereka kenal, yakni ekonomi uang. Munculnya "kemajuan-kemajuan" ini kemudian membawah masyarakat lokal di mana perkebunan besar ini berada menuju sebuah transformasi, yang tidak saja bersifat ekonomi sosial, tetapi juga politis, sosial dan budaya, termasuk di Onderafdeeling Banjoeasin en Koeboestreken. Relevansi antara munculnya dunia modern lewat perkebunan besar, onderneming dan dampaknya terhadap masyarakat lokal yang tradisional di Onderafdeeling Banjoeasin en Koeboestreken yang kemudian membuat hal tersebut menarik untuk dikaji lebih jauh lagi dalam makalah ini.

Berdasarkan latar belakang di atas, maka dalam tulisan ini dirumuskan masalah sebagai berikut: Bagaimana bentang alam dan kependudukan di Onderafdeeling Banjoeasin en Koeboestreken pada masa kolonial? Bagaimana sejarah keberadaan perkebunan besar, onderneming Eropa, di Onderafdeeling Banjoeasin en Koeboestreken? Apakah dampak dari keberadaan perkebunan besar,onderneming Eropa, bagi masyarakat di Onderafdeeling Banjoeasin en Koeboestreken, baik bagi orang Melayu Banyuasin maupun etnis Kubunya? 
Tujuan dan objek tulisan ini adalah suatu relevansi antara keberadaan perkebunan besar, onderneming Eropa dan dampaknya bagi masyarakat di Onderafdeeling Banjoeasin en Koeboestreken pada masa kolonial tahun 1900-1942.

Secara historis, tujuan tulisan ini ingin melihat:

1. Mengkaji hubungan bentang alam dan kependudukan di Onderafdeeling Banjoeasin en Koeboestreken pada masa kolonial dengan peluang munculnya dunia perkebunan pada waktu itu.

2. Mengkaji relevansi keberadaan perkebunan besar, onderneming Eropa, dengan kemajuan-kemajuan bagi Onderafdeeling Banjoeasin en Koeboestreken.

3. Mengkaji dampak dari keberadaan perkebunan besar,onderneming Eropa, bagi masyarakat di Onderafdeeling Banjoeasin en Koeboestreken, baik bagi orang Melayu Banyuasin maupun etnis Kubunya.

Selain itu, tulisan ini dapat memberi manfaat dalam beberapa aspek, yakni:

1. Bagi perkembangan ilmu pengetahuan, tulisan dan hasilnya diharapkan dapat menambah dan memperkuat cakrawala penelitian dalam sejarah ekonomi, sosial dan kebudayaan terhadap keberadan ekonomis dari dunia perkebunan masa lalu dengan lokasi di mana perkebunan tersebut bereksistensi.

2. Bagi pemerintah, diharapkan tulisan ini dapat menjadi refensi utama dalam kebijakan pengembangan ekonomi yang lebih luas dengan perspektif pro rakyat.

3. Bagi masyarakat, diharapkan tulisan ini dapat menjadi masukan berharga dalam hal menyikapi perkembangan-perkembangan "baru" yang ada dilingkup lokal mereka, agar dapat diambil nilai-nilai positif dari kemunculan suatu kebaharuan yang ada dilingkungannya.

Kajian terdahulu tentang karet di Keresidenan Palembang umumnya, Onderafdeeling Banjoeasin en Koeboestrekken khususnya, pada masa kolonial belum terlalu banyak, kalau boleh dikatakan minim. Penelitian utama tentang karet di Keresidenan Palembang datang dari kajian Purwanto tahun 1993 berjudul From Dusun To The Market: Native Rubber Cultivation In Southern Sumatra, 1890-1940. Kajian ini merupakan disertasi di Oxford University London, Inggris yang menekankan pada sejarah ekonomi budidaya karet asli tradisional yang dikelolah oleh masyarakat di daerah uluan Keresidenan Palembang. Purwanto melihat dalam kajian ini bagaimana karet yang dibudidayakan oleh masyarakat, kemudian masuk ke dalam perdagangan internasional, di tengah hegemoni perkebunan-perkebunan swasta besar Eropa yang mulai dan tengah berkembang selama awal abad ke-20.

Kajian berikut tentang karet adalah tulisan Zed tahun 2002 berjudul Ekonomi Dualistis Palembang pada Periode Kolonial Akhir yang menjadi bagian dari buku Fondasi Historis Ekonomi Indonesia dieditori oleh sejarawan ekonomi Thomas J. Lindblad. Meskipun kajiannya ini tidak hanya membicarakan karet, tetapi tanaman ekonomis lain di Keresidenan Palembang, seperti kopi, Kelapa Sawit, Lada, Minyak Bumi dan sebagainya. Menariknya, tulisan Zed 
mencoba mengkaji suatu bentangan komparatif antara usaha pertanian perkebunan besar Eropa, onderneming di satu sisi dengan dihadapkan pada perkebunan kecil rakyat di sisi lainnya.

Selain dua tulisan tersebut, kajian Clemens dalam penelitian studinya di Universiteit van Amsterdam tahun 1988 berjudul De Bevolkingsrubbercultuur in Djambi en Palembang Tijdens het Interbellum, 1906-1942, mengenai perkebunan karet rakyat di Jambi dan Palembang patut diketengahkan. Studi ini merupakan usaha komparatifnya dalam melihat perkebunan karet rakyat di satu sisi dengan onderneming karet besar Eropa di Jambi dan Palembang. Clement dengan sangat menarik mencoba melihat bagaimana usaha perkebunan karet rakyat dalam mensiasati perkembangan harga karet dunia ketika pemerintah kolonial Belanda menjalankan peraturan-peraturan yang ada kalanya bersifat menguntungkan seekaligus merugikan usaha karet rakyat di Jambi dan Palembang.

Kerangka teoretis menerangkan pengertian-pengertian atau konsep dasar tentang topik yang diangkat dalam penulisan ini. Konsep perkebunan, menurut Suwirta (2002: 19-36), berkenaan dengan segala kegiatan yang mengusahakan tanaman tertentu pada tanah atau media tumbuh lainnya dalam ekosistem yang sesuai, mengolah dan memasarkan barang dan jasa hasil tanaman tersebut, dengan bantuan ilmu pengetahuan dan teknologi, permodalan serta manajemen untuk mewujudkankesejahteraan bagi pelaku usaha perkebunan dan masyarakat.

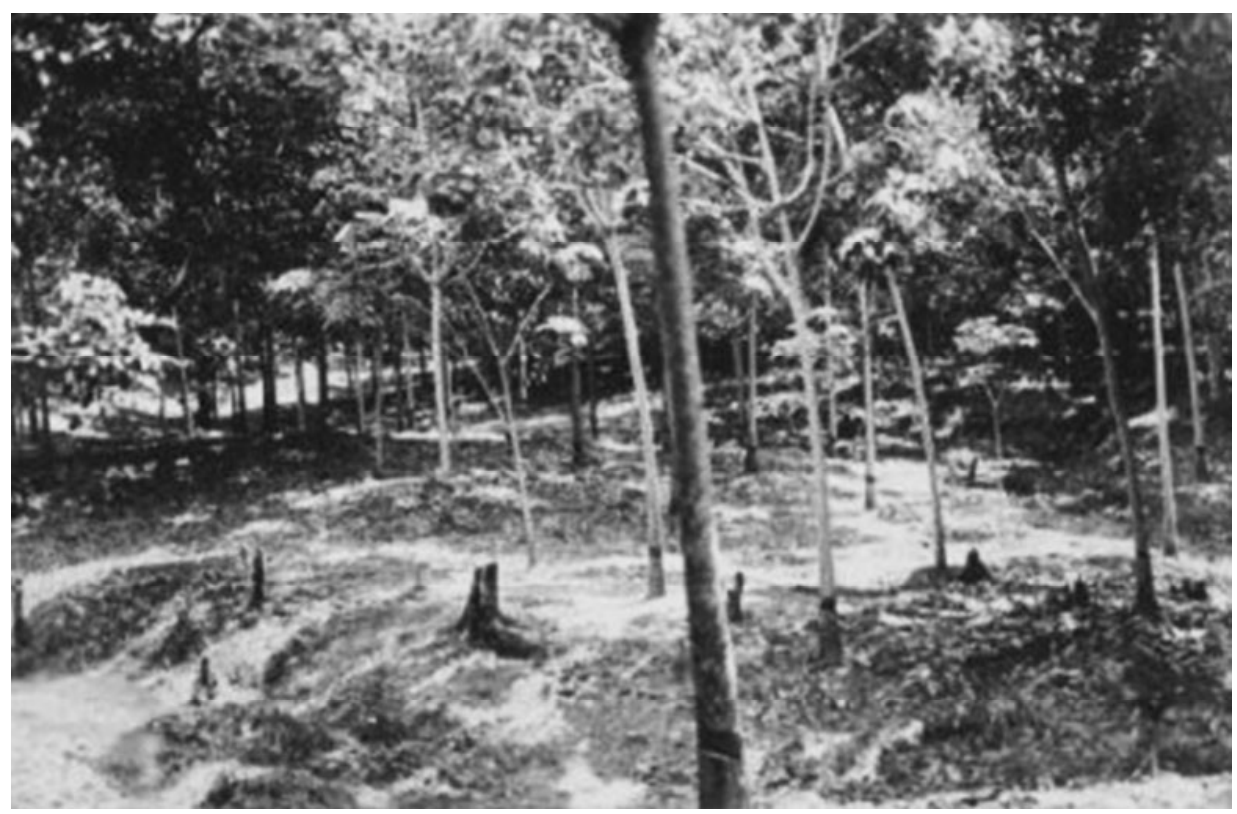

Gambar 3. Peremajaan karet di Perkebunan Tebenan

di Onderafdeeling Banjoeasin en Koeboestrekken, 1938. (Sumber: kitlv.nl)

Sebenarnya, menurut Lindayanti (1994: 34-35) sebelum pemerintah kolonial Belanda datang ke Indonesia, masyarakat pribumi telah mengenal sistem bercocok tanam. Sektor perkebunan, menariknya dalam sejarah Indonesia masa kolonial tidak dapat dipisahkan dan memiliki arti yang sangat penting bagi perekonomian dan kehidupan sosial masyarakat di berbagai wilayah Indonesia. Sistem perkebunan yang dibawa oleh pemerintah kolonial pada dasarnya adalah sistem perkebunan Eropa yang berbeda dengan sistem kebun yang telah lama 
berlaku di Indonesia pada masa pra kolonial. Sebagai sistem perekonomian pertanian baru, sistem perkebunan telah memperkenalkan dan membaharui sistem perekonomian pertanian dan akhirnya memberikan dampak perubahan penting terhadap perubahan masyarakat tanah jajahan. Menurut Kartodirdjo dan Djoko Suryo (1991: 66-67), perkebunan sistem kolonial ini diwujudkan dalam bentuk usaha pertanian skala besar dan komplek, bersifat padat modal, penggunaan areal pertanahan luas, organisasi tenaga kerja besar, pembagian kerja rinci, pengguanaan tenaga kerja upahan, struktur hubungan kerja yang rapi, dan penggunaan teknologi modern, spesialisasi, sistem administrasi dan birokrasi, serta penanaman tanaman komersial yang ditujukan untuk komediti ekspor dipasar dunia. Dalam menjalankan perkebunan, pemerintah kolonial juga memiliki konsep yang dianggap mampu mempermudah kontrol perkebunan.

Sejalan dengan pengertian di atas, menurut Oktasari dan Agus Trilaksana (2014: 122129), acuan pengertian di atas mengarah pada perkebunan besar yang merupakan perkebunan yang diselenggarakan atau dikelola secara komersial oleh perusahaan yang berbadan hukum. Perkebunan besar terdiri dari perkebunan besar negara dan perkebunan besar swasta nasional atau asing. Perkebunan besar biasanya memiliki konsekuensi yang bersifat fungsional yaitu terciptanya lapangan pekerjaan baru, menyokong perekonomian dan status sosial. Oleh karena itu, menurut pengertian Ritzet (2007:139) sebagai sebuah fungsi pasti memiliki konsekuensikonsekuensi yang dapat diamati yang menimbulkan adaptasi atau penyesuaian dari sistem tertentu.

Sistem penguasaan lahan yang diterapkan oleh pemerintah kolonial Belanda di Keresidenan Palembang, termasuk di Onderafdeeling Banjoeasin en Koeboestreken, menurut Zed (2002: 294-312), menerapkan sistem dualistis yakni sistem hukum Eropa dan sistem hukum adat. Pemerintah Kolonial Belanda, dalam sistem penguasaan lahan seperti ini, menggunakan dan memanfaatkan aturan penguasaan lahan dengan sistem kepala daerah, kepala marga, yang dipegang oleh pasirah. Dalam sistem seperti ini, pasirah, sebagai kepala adat marga dikendalikan dalam mengatur tentang adanya pengakuan status lahan adat masyarakat, di mana syarat ada tanah adat yang diserahkan kepada pemerintah kolonial Belanda pada saat itu. Fokus utama kajian penelitian ini adalah pembukaan perkebunan dan dampaknya dalam masyarakat di Onderafdeeling Banjoeasin en Koeboestreken yang merupakan bagian dari suatu masyarakat perkebunan pada masa itu.

\section{B. METODOLOGI}

Metode yang digunakan dalam penelitian ini adalah metode sejarah untuk merekonstruksi mengenai sejarah perkebunan dan dampaknya bagi perkembangan masyarakatdi Onderafdeeling Banjoeasin en Koeboestrekken. Teknik pengumpulan data yang digunakan mengacu dengan tahap pertama dalam metode sejarah yaitu proses heuristik. Heuristik merupakan kegiatan dalam mencari dan mengumpulkan sumber-sumber sejarah yang terdiri dari sumber-sumber tertulis berupa arsip, terbitan pemerintah, buku, dan artikel yang relevan dengan fokus penelitian, koran atau harian sezaman, jurnal, majalah, terbitan berkala, laporan-laporan statistik, dan sebagainya. 
Teknik analisis data berkenaan dengan tahap kedua, ketiga dan keempat dalam metode sejarah yang meliputi kritik sumber, interpretasi dan historiografi. Kritik sumber, menurut Gottschalk (1986: 80-111), adalah kegiatan yang bertujuan untuk menyelidiki dan menguji apakah sumber-sumber sejarah yang ditemukan itu otentik dan bisa dipercaya, kredibel, baik dalam bentuk maupun isinya. Untuk menguji keaslian sumber dilakukan kritik intern, kredibilitas, yaitu menentukan sifat sumber dan kritik ekstern, otentisitas, yakni untuk mengetahui keaslian sumber, apakah sumber itu asli, turunan atau bahkan sudah diubah. Menurut Pranoto (2010: 22), kegiatan interpretasi adalah menetapkan makna dan saling hubungan antara fakta yang satu dengan fakta lainnya sesuai dengan topik dalam penelitian ini berdasarkan hubungan kronologis dan sebab-akibat dengan melakukan imajinasi, interprestasi, dan analisis serta disintesiskan. Fakta-fakta sejarah tentang perkebunan di Onderafdeeling Banjoeasin en Koeboestrekken pada masa lalu yang diperoleh harus dirangkaikan atau dihubung-hubungkan satu sama lain sehingga menjadi satu kesatuan yang harmonis, menurut rangkaian kronologis dan hubungan sebab-akibat. Sementara proses historiografi atau rekonstruksi sejarah berkenaan dengan kegiatan melakukan rekonstruksi peristiwa masa lalu tentang perkebunan di Onderafdeeling Banjoeasin en Koeboestrekken dalam bentuk kisah sejarah yang dituangkan dalam tulisan.

\section{PEMBAHASAN}

\section{a. Onderafdeeling Banjoeasin en Koeboestrekken: Sekilas Pandang}

Saat ini Onderafdeeling Banjoeasin en Koeboestrekken merupakan Kabupaten Banyuasin merupakan pemekaran dari Kabupaten Musi Banyuasin sejak tahun 2002. Menurut tulisan Bappeda Pemkab Banyuasin (2008: 9), kata "Banyuasin" diangkat dan bersumber dari keadaan alamnya yang sebagian besar merupakan wilayah perairan, baik di muara laut maupun aliran sungai dan lebak. Topografis seperti ini hampir mendominasi wilayah Kabupaten Banyuasin. Kata "banyu" memiliki padanan kata dalam Bahasa Indonesia yang berarti "air", sementara kata "asin" merupakan gambaran dari rasa air tersebut. Dengan demikian arti dari banyuasin bersinonim dengan "air asin", air yang memiliki rasa asin.

Kabupaten Banyuasin saat ini, mempunyai wilayah seluas 11.832,99 Km2 dan terbagi menjadi 15 kecamatan. Secara administratif, Kabupaten Banyuasin mempunyai batas wilayah sebagai berikut: sebelah utara berbatasan dengan Kabupaten Tanjung Jabung Timur Provinsi Jambi dan Selat Bangka. Sebelah timur berbatasan dengan Kecamatan Pampangan dan Air Sugihan Kabupaten Ogan Komering Ilir. Sebelah selatan berbatasan dengan Kecamatan Jejawi Kabupaten Ogan Komering Ilir, Kota Palembang, Kecamatan Sungai Rotan dan Talang Ubi Kabupaten Muara Enim. Sementara, sebelah barat berbatasan dengan Kabupaten Musi Banyuasin. (Bappeda Pemerintah Kabupaten Banyuasin. 2014: 56) 


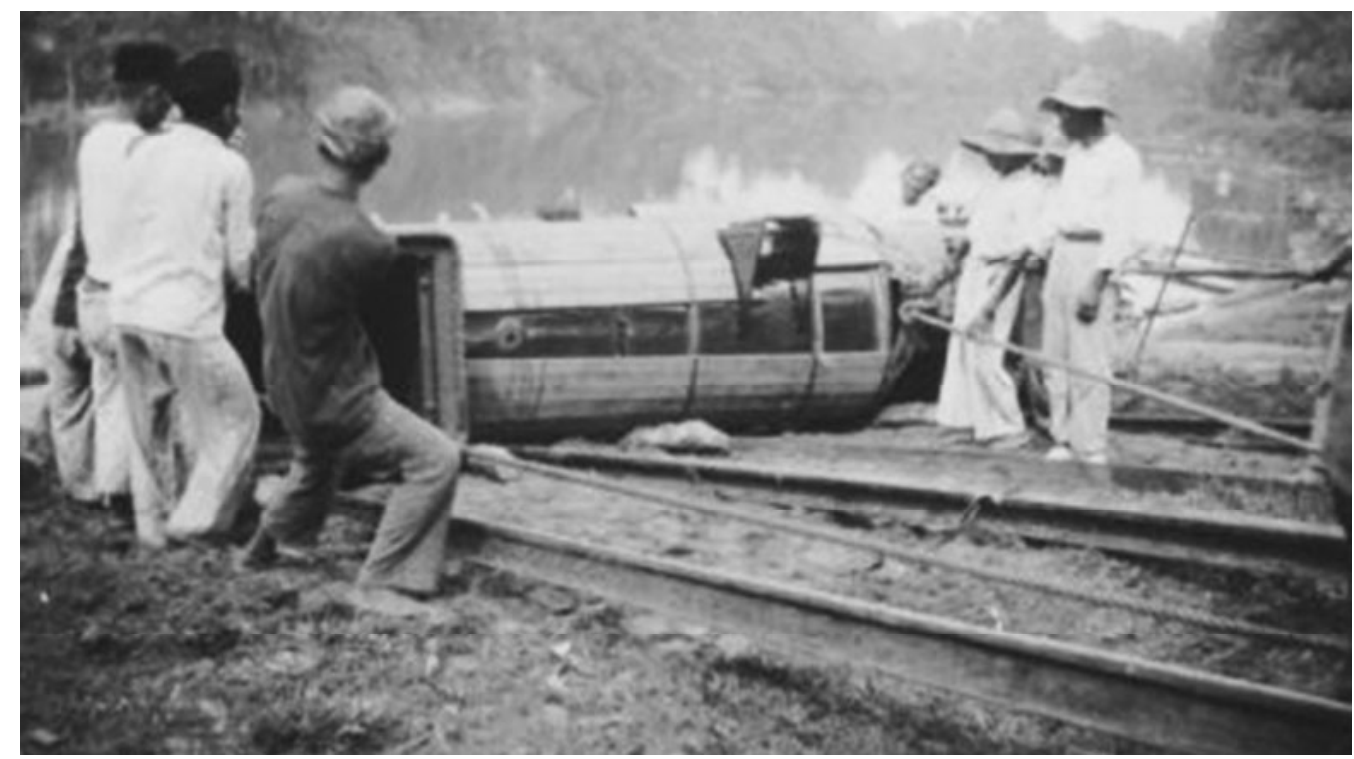

Gambar 4. Penggunaan perauh ketel sebagai alat transportasi dan pengangkutan karet ke luar Perkebunan Tebenan di Onderafdeeling Banjoeasin en Koeboestrekken, 1926. (Sumber: kitlv.nl)

Berdasarkan kondisi topografinya, pada saat ini Kabupaten Banyuasin didominasi oleh daerah yang relatif datar atau sedikit bergelombang, yaitu terdiri dari $80 \%$ luas dataran rendah basah berupa pesisir pantai, rawa pasang surut dan lebak serta $20 \%$ luasan merupakan dataran berombak sampai bergelombang dengan kisaran ketinggian 0-60 meter di atas permukaan laut. Pada masa lalunya, kondisi geografis seperti iniOnderafdeeling Banjoeasin en Koeboestrekken merupakan wilayah yang bentang alamnya sangat dipengaruhi oleh transportasi kehidupan sungai, di mana Onderafdeeling Banjoeasin en Koeboestrekken dialiri sungai besar yang semuanya bermuara ke laut, yang ada di Selat Bangka. Ilustrasi dari peta yang dibuat oleh van Dongen dan Wisly (1910: 337-344) menggambarkan keadaan Onderafdeeling Banjoeasin en Koeboestrekken pada masa lalu tersebut. Dari Tanjung Siapi-siapi sungai besar yang mencabang menjadi Air Banjoeasin, Air Tjaleh dan Air Lalan. Kemudian dari Muara Soengsang dua sungai besar yakni Air Telang dan Air Soengsang. Air Soengsang bertemu dengan Air Oepang membentuk Sungai Musi hingga ke wilayah pedalaman Keresidenan Palembang. Selain sungaisungai panjang ini muara laut juga memiliki sungai pendek Sei Dringoe, Sei Siapa, Sei Sembilan.

Sungai besar utama di Onderafdeeling Banjoeasin en Koeboestrekken adalah Air Banjoeasin yng memiliki anak sungai Air Pontian, Sei Matjan, Sungai Moekoet, Sei Poejoe, Sei Keron, Sungai Ringit, Sungai Simau, Sungai Pangkalan Balai, Sungai Iboel, Air Banteng. Air Saleh dan Air Banjoeasin bertemu yang melahirkan anak sungai Air Toengkal. Air Toengkal memiliki anak-anak sungai yakni Air Betong, Air Betong, Sei Seremoeu, Air Dawas, Sei Tigas, Sungai Ajau, Sungai Ladjoe, Sungai Kloewang Besar, Sungai Petidoeran, Sungai Temiang, Air Toengkal, Sungai Bentajan, Sungai Penoedoean, Sungai Gresik, Sungai Boeaja. Air Toengkal berakhir di Pangkalan Toengkal. Aliran sungai ini berpangkalan di daerah bagian ulu mulai dari daerah barat pangkalan untuk Air Tungkal. Sementara Air Dawas, berulu di Dawas pada bagian utaranya, Soepat dan Babat pada bagian tengahnya, serta Betong pada bagian selatannya. 
Sei Lalan yang berpangkalan di Pangkalan Benteng di utara sedang Pangkalan Brondong di selatan memiliki anak-anak sungai Sei Merang, Sungai Kenawang, Sungai Mangsang, Air Medak, dari sana terus ke Bajoeng Lentjir kemudian memiliki anak-anak sungai, yakni Sungai Bahar, Sungai Mendis, Air Randang, Sungai Tadjau, Sungai Boehan, Sungai Penerokan, Air Jernih, Sungai Dajo, Sungai Moetoeng, Sungai Temidan, dan Sungai Boelian, Sungai Kandang, Sungai Penjeroan, dan Sei Boengin, Sungai Bengkoeningan, Sungai Boeloe, Sungai Badak, Sungai Krekai, Sungai Bajat, Air Berao.

Air Telang memiliki anak sungai, yakni Sei Jaran, Air Gasing, Air Kenten. Selain itu, setelah Air Soengsang bertemu dengan Air Oepang dan membentuk sungai Musi untuk menuju Palembang. Namun di antara pertengahan antara Palembang dan Sekajoe, Sungai Moesi bercabang, di mana cabangnya bagian utaranya disebut Batang Hari Leko yang masuk ke Onderafdeeling Banjoeasin en Koeboestrekken. Sungai Batang Hari Leko memanjang dibagian selatan Onderafdeeling Banjoeasin en Koeboestrekken membentuk aliran dengan anak sungai, yakni Sungai Rampasan, Sei Napal, Sei Dangkoe, Sungai Roekoei, Sungai Boenoet. Kemudian di daerah Bintialo, Batang Hari Leko memiliki cabang anak sungai yakni Air Meranti dan Air Rapas. Air Meranti memiliki anak sungai, yakni Sungai Anggang Besar dan Sungai Anggang Kecil, Sungai Pemainan, dan Sungai Poeting Belioeng. Sementara Air Rapas memiliki anak sungai, yakni Sungai Hoel dan Sungai Mengkelag.

Di sepanjang daerah aliran sungai-sungai tersebut, menurut van Dongen dan Wesly (1910: 337-3344), kemudian membentang tujuh marga utama di Onderafdeeling Banjoeasin en Koeboestrekken yakni Marga Koeboe Lalan yang mendiami daerah aliran sungai Air Lalan bagian ilir, Marga Koeboe Bajat yang mendiami daerah aliran sungai serta anak-anak sungai Air Lalan bagian ulu, Marga Koeboe Toengkal yang mendiami sepanjang daerah aliran sungai dan anak-anak sungai Air Toengkal bagian ulu, Marga Toengkal Ilir yang mendiami sepanjang daerah aliran sungai Air Toengkal bagian ilir, Marga Dawas yang mendiami sepanjang daerah aliran Air Dawas, Marga Soepat yang mendiami daerah aliran sungai Dawas dan anak-anak sungai Air Dawas bagian ilir, dan Marga Koeboe Oeloe Leko yang mendiami aliran bagian ulu Batang Hari Leko di selatan Onderafdeeling Banjoeasin en Koeboestrekken.

Keadaan geografis yang demikian membuat Onderafdeeling Banjoeasin en Koeboestrekken, walaupun dekat dengan pusat kuasa, ibukota Palembang menjadi daerah yang terisolir karena sulitnya perhubungan. Menariknya hampir semua daerah bagian utaranya sangat sulit berhubungan dengan ibukota Palembang karena sungai-sungai besar beserta anak sungainya tersebut tidak memiliki pertemuan dengan Sungai Musi. Jadi, daerah yang paling memungkinkan berhubungan langsung dengan ibukota Palembang Secara administratif, berdasarkan tulisan de Bruyn (1919: 33-34), wilayah onderafdeeling, seperti halnyaOnderafdeeling Banjoeasin dan adalah daerah selatan yang dialiri Air Batang Hari Leko yang merupakan daerah Marga Koeboe Oeloe Leko.

Koeboestrekken dibawah kendali seorang kontroleur yang bertugas mengumpulkan datadata informasi dan melaksanakan semua perintah atasannya, sebagai pengawas dan tidak ikut campur tangan dalam institusi-institusi marga yang dikelola pribumi. Di bawah kedudukan 
kontroleur ada jabatan Demang yang mengepalai wilayah distrik, dimana diOnderafdeeling Banjoeasin dan Koeboestrekken terdiri dari dua distrik, distrik Talang Betoetoe dan distrik Bajoeng Lincir. Demang membawahi kekuasaan asisten Demang, di mana di Onderafdeeling Banjoeasin dan Koeboestrekken ada lima wilayah onderdistrik, yakni onderdistrik Talang Betoetoe, onderdistrik Pangkalan Balai, onderdistrik Pradjen, onderdistrik Bajoeng Lincir, dan onderdistrik Dawas. Namun, sekitar tahun 1930, daerah distrik dan onderdistrik dihapuskan, termasuk jabatan Demang dan Asisten Demang yang kemudian ditarik ke kantor kepala onderafdeeling dengan bekerja langsung di bawah perintah kontroleur sebagai asisten pemerintahan.

Pada masa kolonial, menurut Hasan (2007: 41), Onderafdeeling Banjoeasin dan Koeboestrekken terbagi dalam dua puluh satu Marga. Secara lengkap pada masa kolonial Belanda, marga-marga yang ada dalam onderafdeeling Banjoeasin dan Koeboestrekken adalah Marga Pangkalan Balai, Marga Talang Kelapa, Marga Soeak Tapeh, Marga Rimbo Asam, Marga Rantaoe Bajoer, Marga Babat, Marga Gasing, Marga Tandjoenglaga, Marga Soengai Rengas, Marga Soengsang, Marga Oepang, Marga Moeara Talang, Marga Koembang, Marga Soengai Aren, Marga Dawas, Marga Soepat, Marga Lalan, Marga Bayat, Marga Toengkal, Marga Bajoeng Lincir dan Marga Penoegoean. Batas antar marga-marga ini dibatasi oleh daerah aliran sungai. Letak Marga yang ditepi sungai dengan segala tapal batas sungainya memperkuat kanyataan historis, bahwa sungai merupakan urat nadi kehidupan masyarakat di Banyuasin sejak masa dahulu. Sungai menjadi alat penting dalam transportasi, perdagangan, penyebaran kekuasaan dan kebudayaan. Hampir semua dusun dalam marga di Onderafdeeling Banjoeasin en Koeboestrekken dibangun di pinggir-pinggir sungai dan muara anak sungai atau dipersimpangan sungai hal ini dilakukan untuk menghindari isolasi alam yang akan membawa isolasi batin bagi masyarakatnya.

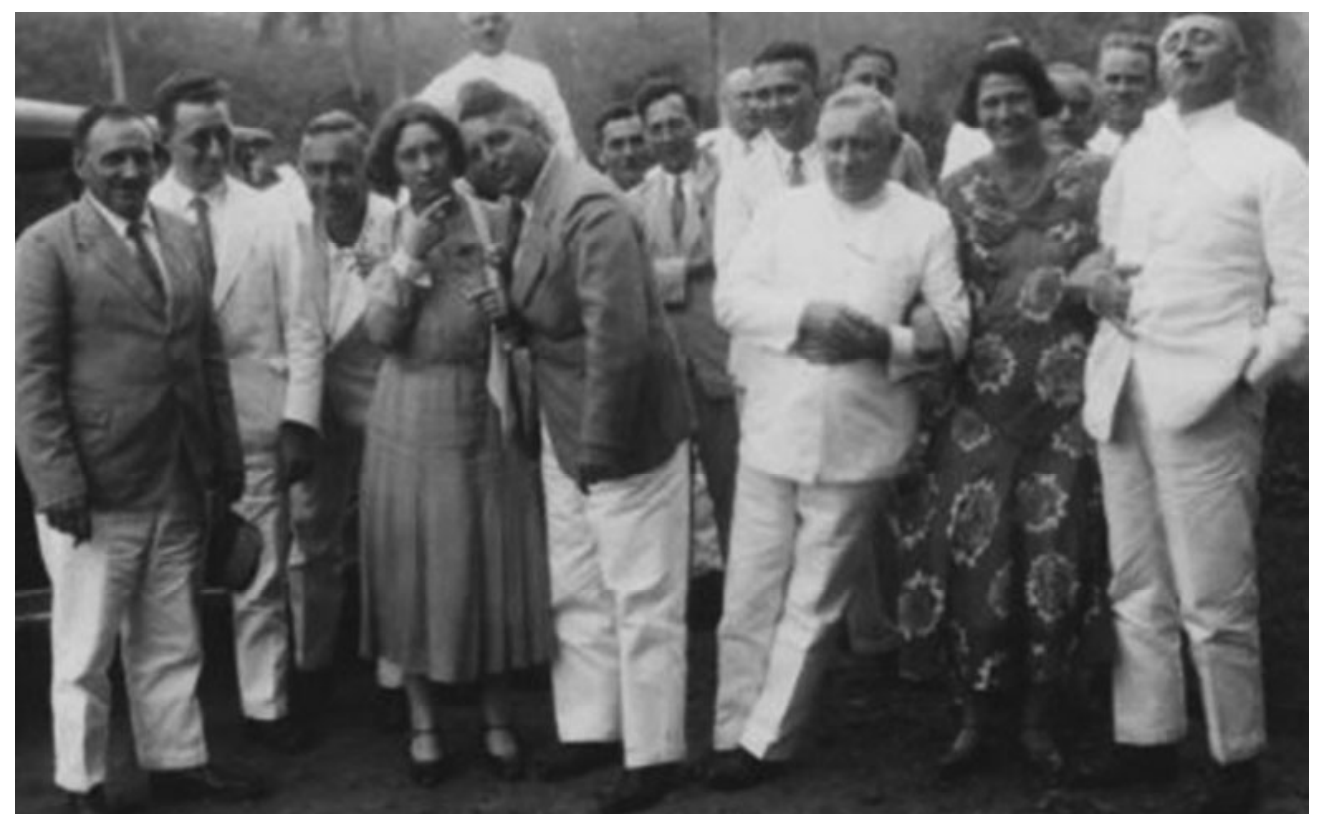

Gambar 5. Kehadiran masyarakat Barat sebagai pegawai perkebunan Tebenan di Onderafdeeling Banjoeasin en Koeboestrekken membawa dampak besar bagi masyarakat pribumi, 1938. (Sumber: kitlv.nl) 
Ada empat fenomena pada masa kolonial sepanjang awal abad ke-20 yang sedikit mengubah geografis Onderafdeeling Banjoeasin en Koeboestrekken seperti itu, pertama, penempatan Kontroleur yang semula berkedudukan di Talang Betoetoe kemudian dipindahkan dan berkedudukan di Bajoeng Lintjir pada tahun 1910. Kedua, yang tidak kalah pentingnya adalah diciptakannya jalan darat pertama di Onderafdeeling Banjoeasin en Koeboestrekken yakni jalan sepanjang $238 \mathrm{Km}$ yang dibangun sepanjang tahun 1903 sampai dengan 1909 membentang dari ibukota Palembang menuju daerah Soepat terus ke Sekajoe hingga ke Moeara Roepit. (Cramer, 1917: 7) Jalan darat ini memangkas waktu dan jarak tempuh semua daerah yang ada di Onderafdeeling Banjoeasin en Koeboestrekken. Dua fenomena lagi menurut tambahan Van Hasselt (1922: 285) adalah fenomena ketiga dan keempat. Ketiga, maraknya perkebunan besar swasta yang dikelolah penanam modal Eropa di Onderafdeeling Banjoeasin en Koeboestrekken. Keempat, ditemukannya dan dilakukannya eksploitasi minyak di Onderafdeeling Banjoeasin en Koeboestrekken serta Onderafdeeling Moesi Ilir.

\section{b. Kependudukan di Onderafdeeling Banjoeasin en Koeboestrekken}

Berdasarkan toponiminya atas penyebutan nama Onderafdeeling Banjoeasin en Koeboestrekken, secara kultural mengandung dua dikotomis wilayah berbeda. Pertama, wilayah Onderafdeeling Banjoeasin en Koeboestrekken, yang terdiri dari suku Banjoeasin, yang dianggap sebagai wilayah dan masyarakat yang lebih "modern" dan secara geografis berada di sebelah selatan atau di wilayah iliran aliran sungai besar Air Banjoeasin. kedua, Onderafdeeling Banjoeasin en Koeboestrekken, yang terdiri dari kelompok masyarakat Kubu yang dianggap masih sangat "tradisional" berada pada wilayah utara atau di bagian ulu anak-anak sungai aliran sungai Air Banjoeasin.

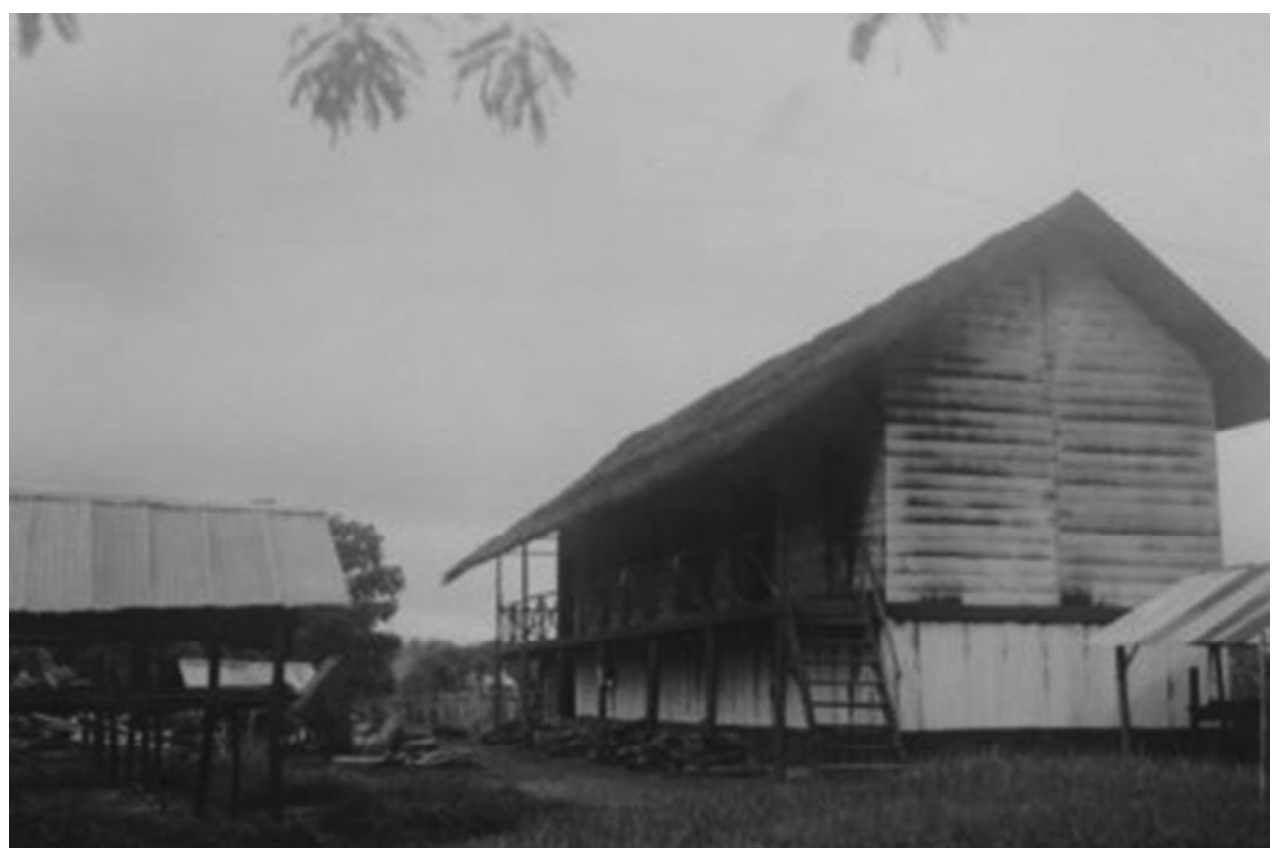

Gambar 6. Pabrik pengasapan karet di Area Perkebunan Tebenan di Onderafdeeling Banjoeasin en Koeboestrekken, 1935. (Sumber: kitlv.nl) 
Berdasarkan itu, menurut Hasan, dkk (2007: 12) secara etnografi pada masa kolonial, terdiri dari dua etnis utama yaitu daerah yang disebut Banjoeasin, di mana marga-marga daerah ini umumnya didiami oleh etnis yang disebut "Melayu Banjoeasin". Orang-orang etnis "Melayu Banyuasin", umumnya berdiam di aliran sungai-sungai di Air Banyuasin, meliputi Marga Talang Kelapa, Marga Soeak Tapeh, Marga Rimbo Asam, Marga Rantaoe Bajoer, Marga Gasing, Marga Tandjoenglaga, Marga Soengai Rengas, Marga Soengsang, Marga Oepang, Marga Moeara Telang, Marga Koembang, dan Marga Soengai Aren. Mereka ini sebetulnya orang Melayu yang tinggal di air, mendirikan rumah kayu bertiang di antara pohon-pohon nipa sepanjang sungai. Baragama dan berkebudayaan Islam. Asal usul orang Melayu Banyuasin ini berasal dari dua gelombang, yakni mereka yang merupakan pasukan Kerajaan Sriwijaya yang lari ke pedalaman, terutama pada masa akhir kerajaan Sriwijaya dan orang-orang yang langsung datang dari Malaka. Kemudian etnis kedua adalah masyarakat Kubu yang ditinggal di kawasan margamarga yang dianggap sebagai daerah Koeboestrekken yang meliputi daerah utamanya Kubu Lalan, Kubu Bajat, Kubu Toengkal, Kubu Toengkal Ilir, Kubu Dawas dan Kubu Supat serta Kubu Batang Hari Leko. Etnis Kubu di Onderafdeeling Banjoeasin en Koeboestrekken ini umumnya sangat dominan di Marga Dawas, Marga Soepat, Marga Lalan, Marga Bajat, Marga Toengkal, dan Marga Bajoeng Lincir. Selain itu ada marga yang secara teritorial terdiri dari campuran dari sebagain etnis Melayu dan dan sebagai etnis Kubu di Onderafdeeling Banjoeasin en Koeboestrekken seperti Marga Babat, Marga Rantaoe Bajoer dan Marga Penoegoean.

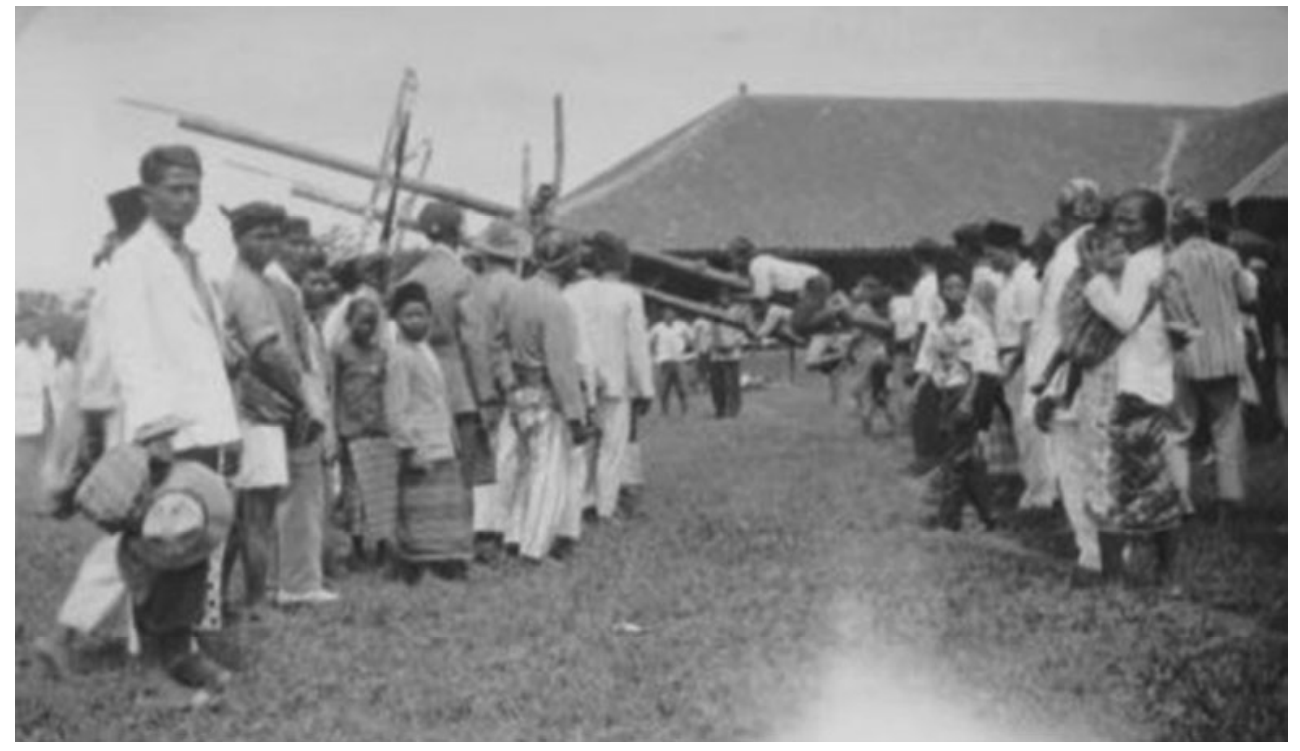

Gambar 7. Masyarakat lokal juga hadir di Perkebunan Tebenan di Onderafdeeling Banjoeasin en Koeboestrekken, baik sebagai buruh maupun ikut dalam kegiatan-kegiatan perayaan di perkebunan, 1930. (Sumber: kitlv.nl)

Menariknya, penjelasan dalam tulisannya tentang Kubu di Onderafdeeling Moesi-Ilir en Koeboestrekken, H. Keelewer (1940: 357-396), membagi marga di onderafdeeling ini dalam lima kategori marga, yakni: Pertama, Marga-margaMusi terdiri dari marga SangaDesa, marga Poendjoeng, marga LawangWetan, marga TeloekKidjing, marga SungeiKeroeh, dusunTanah AbangdarimargaPinggap. Kedua, Marga-MargaEpil, Babat, Soepat. Ketiga, MargaDawas. 
keempat Marga-margaPenoekaldanAbab. Dan kelima, marga-marga Kubu yang terdiri dari margaBatang HariLeko, marga KubuToengkalulu, marga Kubu Bajat, marga KubuLalan, yang sebagian dusun Pengatoeran, dusun Loeboek, dusun Boeah, dusun SungaiNapaldan dusunSaoetTalang Saoet, dusunTalangBoeloehdan serta sebagian dusun-dusun di margaPinggap.

Ditambahkan secara tegas masyarakat Kubu di Onderafdeeling Banjoeasin en Koeboestrekken ini dalam catatan van Dongen dan Wesly (1910: 179-336) memiliki akar yang berbeda dengan masyarakat Kubu yang ada di Jambi. Jika masyarakat Kubu di Onderafdeeling Banjoeasin en Koeboestrekken berasal dari pemukiman kuno Sungai Beloloes, sementara masyarakat Kubu di Jambi berasal dari keturunan Kubu Semamboe. Dalam catatan van Dongen tersebut, pada tahun 1907 total populasi orang Kubu ini sebesar 7.594 jiwa, yang hidup di marga Kubu Lalan, Kubu Toengkal, Kubu Bajat, Kubu Ulu Leko, marga Soepat dan Marga Toengkal Ilir.

Menurut H. Keeleweer, mereka disebut Kubu yang sudah maju, Koeboestrekken, kata strekken, sudah maju, menyiratkan bahwa suku kubu tersebut merupakan suatu komunitas masyarakat yang digolongkan tidak lagi terbelakang, dan secara administrasi sudah bisa dikendalikan dengan baik oleh Pemerintah Kolonial Belanda. Kata Strekken diberikan karena mereka sudah tidak telanjang lagi, walaupun hanya memakai cawat ikat pinggang sebaga satusatunya penutup tubuh, sudah memiliki gaya hidup menetap dengan rumah sangat sederhana kajang yang ditutupi atap berbentuk anjing beruang yang sedang mengangah, rumah terbuka. Kemudian unsur-unsur Islam sudah masuk dalam kehidupannya dengan masuk sebagai pemeluk agam Islam, meskipun kepercayaan akan nenek muyang masih sangat kuat. Serta adanya aturan hidup dalam sebuah komunitas berbentuk marga yang dikendalikan oleh pasirah.

\section{c. Perkebunan Pada Masa Kolonial di Onderafdeeling Banjoeasin en Koeboestrekken}

Pada masa kolonial, menjelang pertengahan abad ke-20, di tanah uluan Keresidenan Palembang, termasuk juga di daerah Onderafdeeling Banjoeasin en Koeboestrekken, seiring dengan penerapan desentralisasi dan perubahan dalam sistem politik "open the door", mulai banyak mengalir para pemodal besar asing yang menanamkan investasinya dalam bidang perkebunan-perkebunan besar dan perminyakan. Daerah Onderafdeeling Banjoeasin en Koeboestrekken, memiliki kekayaan mineral dan sangat baik untuk daerah perkebunan, terutama tananam karet. Keadaan alam yang seperti ini, menimbulkan lahirnya perusahaan-perusahaan minyak dan gas bumi, usaha pertambangan mulai dibuka di daerah Sungai Lilin dan Keluang.

Selain minyak bumi dan gas, keberadaan Onderafdeeling Banjoeasin en Koeboestrekken secara geografis di daerah dataran rendah menyebabkan wilayah ini memiliki dua jenis topografis yaitu tanah talang dan tanah lebak. Tanah lebak sangat cocok untuk melakukan penanaman padi dan tanah talang dapat dimanfaatkan sebagai daerah perkebunan. Untuk kedua jenis topografis ini, Onderafdeeling Banjoeasin en Koeboestrekken sangat ditunjang oleh keadaan iklim yang baik dengan musim pergantian yang menguntungkan bagi kedua usaha agraria tersebut. Di daerah Onderafdeeling Banjoeasin en Koeboestrekken, juga memiliki kekayaan dalam hal kecocokan tanah dengan tanaman para atau karet yang cukup laku di pasaran Internasional. Sehubungan dengan dibukanya politik ekonomi "open the door", maka di daerah 
ini masuk perusahaan-perusahaan asing yang didominasi oleh orang-orang Eropa, terutama Belanda dan Belgia.

Di Keresidenan Palembang, dalam hal ini di Onderafdeeling Banjoeasin en Koeboestrekken, pada tahun 1909 berdiri perkebunan besar karet pertama bernama Rubber Ondernemingen Melaniadi bawah bendera perusahaan-perusahaan Internasional Belgia, bernama perusahaan Sociente Financiere des Caoutchoues. Perkebunan Rubber Ondernemingen Melaniamelakukan penanaman dan usaha karet secara besar-besaran mulai dari ujung timur Marga Pangkalan Balai sampai ke ujung barat Marga Gasing. Perusahaan perkebunan, Rubber Ondernemingen Melania di Onderafdeeling Banjoeasin en Koeboestrekken ini berpusat di Musi Landas. Melenia Musi Landas ini merupakan budidaya tanaman karet Melania, sekaligus memiliki pabrik pengolahan karet yang menghasilkan produk RSS, ribbed smoked sheet, dengan kapasitas 10 ton karet kering per hari.

Kemudian perusahaan internasional Amerika yang bernama Handelsvereeniging Amsterdam (HVA)pada tahun 1910 membuka perkebunan karet dan kepala sawit di Onderafdeeling Banjoeasin en Koeboestrekken dengan nama Oud Wassenaar, N.V. Oliepalmen en rubber Mij. Perusahaan Perkebunan Karet dan kepala sawit Oud Wassenar membentang luas di daerah-daerah talang mulai bagian utara Batang Hari Leko, Marga Rantau Bayur, ke utaranya Marga Suak Tape, Marga Betung dan daerah Tebenan. Selain, menanam dan menguasai karet mereka juga memiliki pabrik karet besar di Tebenan yang merupakan unit usaha perkebunan milik Belanda di Onderafdeeling Banjoeasin en Koeboestrekken yang bergerak di bidang perkebunan karet, Tebenan saat ini berlokasi di Desa Suka Mulya Kecamatan Betung Kabupaten Banyuasin, Sumatera Selatan. Unit usaha tersebut dikemudian hari setelah Indonesia merdeka dinasionalisasi kedalam perusahaan milik negara PT. Perkebunan Nusantara VII, PTPN VII, yang berkantor pusat di Bandar Lampung.A.J.G Stevels ditunjuk sebagai sebagai administratur perkebunan karet Oud Wassenaar yang berpusat di Tebenan.Oud Wessenaar Tebenan ini selain memiliki pabrik pengolahan karet yang menghasilkan produk SIR 20 dengan kapasitas 40 ton karet kering per hari, juga merupakan unit budidaya tanaman karet pada waktu itu.

Selain usaha karet, perusahaan perkebunan Oud Wassenar di Onderafdeeling Banjoeasin en Koeboestrekken juga melakukan usaha perkebunan kepala sawit yang berpusat di Betung, di mana selain memiliki pabrik pengolahan kelapa sawit dengan kapasitas 60 ton TBS per jam juga memiliki usaha kebun budidaya kelapa sawit. Selain Betung, perkebunan kelapa sawit Oud Wassenaar di Onderafdeeling Banjoeasin en Koeboestrekken ini juga memiliki pabrik di daerah Talang Sawit, di mana kedua pabrik ini didukung oleh kebun budidaya dan usaha tanaman Betung Krawo dan Bentayan yang dari sana sawit kemudian produksinya dikirim untuk diolah di Betung dan Talang Sawit.

Menurut Zed (2002: 294-312), harga karet yang membumbung pada tahun 1910 dan 1911 menambah semangat para pengusaha perkebunan untuk mengembangkan usahanya di Onderafdeeling Banjoeasin en Koeboestrekken. Walaupun demikian, pada tahun 1920-1921 terjadi depresi perekonomian dunia yang membuat harga karet merosot. Namun pada tahun 1922 dan 1926 terjadi ledakan harga lagi karena kurangnya produksi karet dunia sementara industri mobil di Amerika meningkatkan jumlah permintaan karet. 
Menurut Purwanto (2015: 12), tanah yang merupakan salah satu alat produksi pokok telah mengalami liberalisasi, sehingga terbukalah kesempatan seluas-luasnya bagi swasta untuk membuka perusahaan perkebunan. Monopoli tanah oleh perusahaan perkebunan berlangsung terus menerus. Maka, seperti halnya di Sumatera Timur, keberhasilan usaha perkebunan di Keresidenan Palembang, termasuk Onderafdeeling Banjoeasin en Koeboestrekken, sebenarnya tidak bisa dilepaskan juga dari keberhasilan perusahaan-perusahaan Belanda dan Eropa Asing lainnya dalam melakukan negosiasi dan mempengaruhi para penguasa lokal, terutama di daerah uluan yang otonom dalam bentuk pemerintahan marga yang dipegang para pasirah. Melalui pemerintah kolonial Belanda, perusahaan-perusahaan Belanda dan Eropa asing ini menjalin perjanjian dan menandatangani kontrak jangka panjang untuk menyediakan lahan perkebunan yang luas.

Pembukaan perkebunan-perkebunan besar ini, pada dasarnya menyebabkan munculnya dualisme ekonomi di kalangan masyarakat daerah Onderafdeeling Banjoeasin en Koeboestrekken, tanah marga untuk kesejahteraan masyarakatnya banyak yang dikuasai oleh perusahaan perkebunan yang mempunyai modal kapital yang sangat besar. Namun kemunduran kesejahteraan di kalangan masyarakat bawah ini, menimbulkan kesejahteraan di kalangan atas daerah uluan ini, para penguasa formal tradisional seperti Pesirah, Kerio, Pembarap dan lainlain dapat memanfaatkan situasi ini dengan memperkaya diri. Perusahaan-perusahaan besar asing dalam memiliki tanah dengan cara berkolusi pada para penguasa formal tradisional, setelah mendapat tanah perusahaan besar ini juga memberi prioritas kepada mereka dalam memiliki tanah-tanah luas untuk ditanami karet secara luas.

\section{d. Dampak Perkebunan Terhadap Masyarakat di Onderafdeeling Banjoeasin en Koeboestrekken}

Sebelum pembukaan onderneming karet di Onderafdeeling Banjoeasin en Koeboestrekken, masyarakat sudah melakkukan penanaman karet yang diproduksi secara tradisonal, karet rakyat. Bahkan menurut Wellan (1932: 226) produksi karet rakyat selalu melebih produksi karet onderneming di Keresidenan Palembang dalam kurun waktu 1921-1930. Menurut Zed (2003: 68), hampir bersamaan dengan ditempat lainnya di Hindia Belanda, di Keresidenan Palembang, termasuk di Onderafdeeling Banjoeasin en Koeboestrekken, sejak akhir oaruh kedua abad ke-19, mulai terbuka sebagai daerah ekspoitasi ekonomi dengan proyek onderneming, perkebunan-perkebunan besar Eropa. Pada tahun-tahun tersebut di Keresidenan Palembang, termasuk Onderafdeeling Banjoeasin en Koeboestrekken, para pengusaha Eropa memperoleh kemudahan akibat adanya pemberian konsesi terhadap tanah-tanah erfpacht, tanah-tanah yang dapat dikelolah dengan sistem sewa selama 75 tahun. Menariknya, pembukaan lahan perkebunan besar di Keresidenan Palembang, tidak menghambat dan menahan pertumbuhan ekonomi rakyat, namun justru berjalan seiring walau kadang kalah bersaing dalam hal tanaman dagang yang sama, seperti karet. Artinya, sifat umum onderneming karet di Keresidenan Palembang, dapat dikatakan nyaris tidak berhubungan dan mengganggu sistem pertanian tradisional karet rakyat setempat, termasuk Onderafdeeling Banjoeasin en Koeboestrekken. Kehadiran onderneming 
ini justru menciptakan apa yang disebut dengan munculnya kapitalis ekonomi di Keresidenan Palembang, dalam hal ini termasuk di Onderafdeeling Banjoeasin en Koeboestrekken.

Onderneming, perkebunan besar di Keresidenan Palembang, hampir 60 persen perusahaannya dimiliki oleh orang Belanda, 34 persen oleh orang Inggris, dan sisanya 6 persen diusahakan oleh orang Jerman, Swiss dan Belgia. Menurut Peeters (1997: 53), perusahaanperusahaan tersebut umumnya juga terdapat di Onderafdeeling Banjoeasin en Koeboestrekken. menariknya, transaksi produksi karet rakyat di Onderafdeeling Banjoeasin en Koeboestrekken langsung berhadapan dengan para touke getah, yang kemudian setelah terkumpul banyak menjualnya pada para perusahaan importir karet seperti Borsumij, NV Palembang Rubber, atau $n v$ Hok Tong di Kota Palembang. Dari sini terlihat bahwa karet rakyat dan onderneming karet di Onderafdeeling Banjoeasin en Koeboestrekken umumnya jarang bersentuhan dalam hal produksi dan pengolaan karet masing-masing

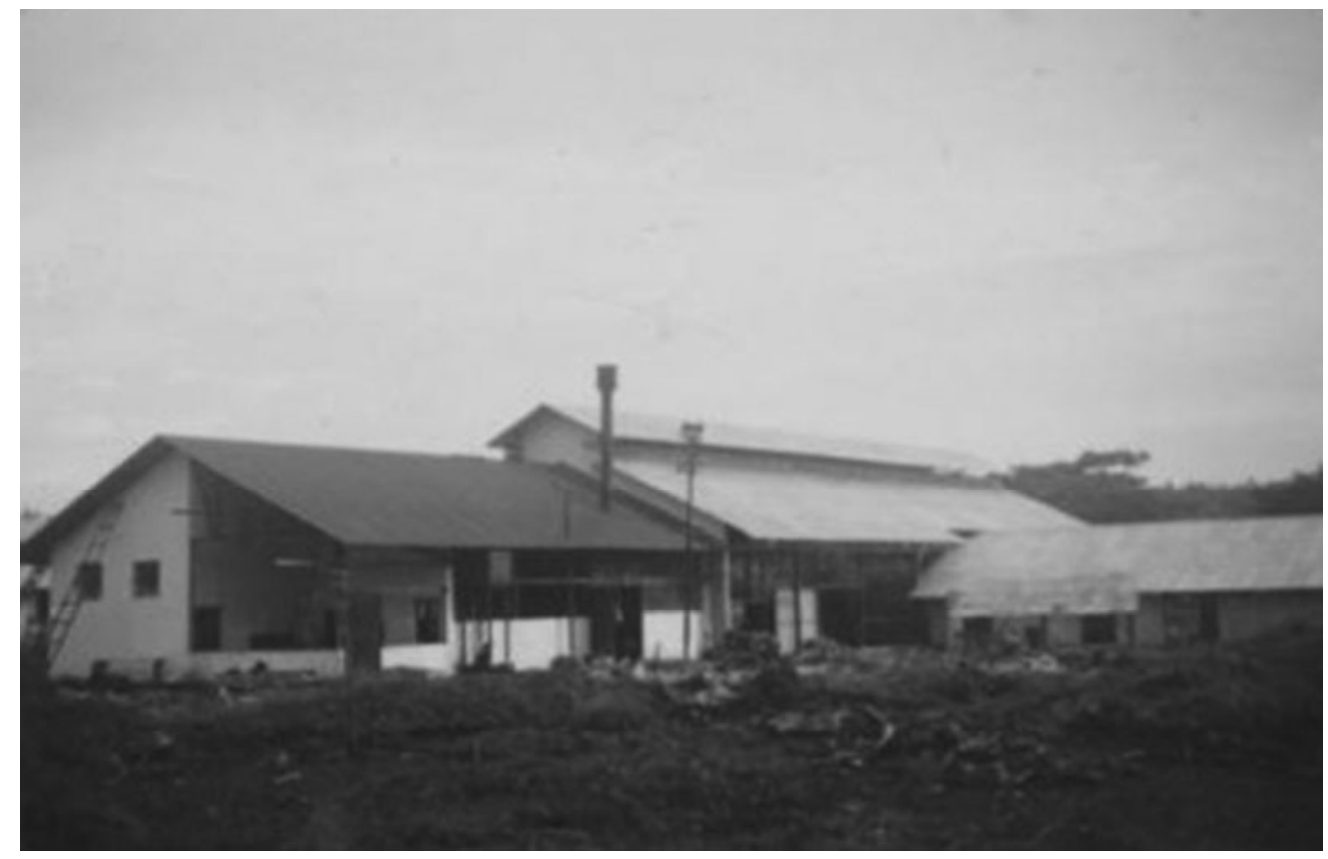

Gambar 8. Pembangunan pabrik karet utama di area perkebunan Tebenan di Onderafdeeling Banjoeasin en Koeboestrekken, 1938. (Sumber: kitlv.nl)

Hubungan pertalian perkebunan dan masyarakat di Onderafdeeling Banjoeasin en Koeboestrekken terasa dalam beberapa hal kemudian sebagai dampak turunan dari kehadiran onderneming asing ini. Pertama, kehadiran onderneming di Onderafdeeling Banjoeasin en Koeboestrekken, terlihat dari adanya perubahan posisi elit lokal, para pasirah, kerio, pejabat dewan marga lainnya. Kenyataan, bahwa bahwa sebagaian besar onderneming karet dan sawit di Onderafdeeling Banjoeasin en Koeboestrekken dibuka pada lahan-lahan hutan tropis yang belum dihuni oleh penduduk, yang merupakan tanah adat, kemudian statusnya diubah oleh pemerintah kolonial Belanda, menjadi tanah milik penguasa lokal, di mana para pengusaha asing Eropa kemudian dapat menyewanya melalui hak konsesi. Akibatnya, konsensi yang dijalankan dengan para elit marga di Onderafdeeling Banjoeasin en Koeboestrekken telah 
menempatkan posisi pejabat-pejabat marga menjadi "penguasa" marga. Mereka mampu menikmati keuntungan ganda berupa manipulasi terhadap produsen dan imbalan yang diterima dari penguasa kolonial Belanda.

Kedua, hadirnya onderneming, perkebunan besar Eropa di Onderafdeeling Banjoeasin en Koeboestrekken, turut menciptakan "perbaikan" sarana dan prasana infrastruktur masyarakat di sana. Perkebunan besar tersebut, baik NV Oliepalmer en Rubber Mijn Oud Wesennaar di Tebenan, Betung serta di Pangkalan Balai maupun Rubber Ondernemingen Melania di Musi Landas, selain membangun empalsemen, pabrik pengolahan hasil perkebunan, mereka juga membangun fasilitas perumahan bagi administrator dan staf, serta kantor. Kemudian, di sekitar pabrik juga dibangun fasilitas untuk memenuhi keperluan orang Eropa seperti gereja dan rumah sakit. Sedangkan untuk menampung keperluan masyarakat diciptakan pasar musiman setiap hari gajian yang selanjutnya berkembang pesat sehingga perlu dibuatkan pasar khusus. Tempat yang memiliki berbagai fasilitas seperti ini yang kemudian berhasil menarik masyarakat di dusun-dusun marga di sekitar onderneming maupun masyarakat luar pada Onderafdeeling Banjoeasin en Koeboestrekken untuk datang dan dan berusaha di berbagai kegiatan seperti membuka usaha pengolahan hasil serta industri pedesaan lain maupun membuka warung dan pelayanan seperti bengkel grobag dan jasa lainnya.

Ketiga, insfrastruktur ini secara tidak langsung, mampu mendorong berkembangnya kegiatan ekonomi dan memberikan dampak yang luar biasa di dusun-dusun marga di Onderafdeeling Banjoeasin en Koeboestrekken. Baik di Tebenan, Pangkalan Balai, maupun Musi Landas, dan terutama di Betung tumbuh sebagai kota kecil di Onderafdeeling Banjoeasin en Koeboestrekken yang juga terdapat pelayanan sosial yang lain seperti kantor pemerintah, sekolah, gereja atau masjid, rumah sakit, pegadaian serta kantor polisi dan pos militer. Perkembangan infrastruktur ini pada saat yang sama kemudian mampu memacu masyarakat di Onderafdeeling Banjoeasin en Koeboestrekken untuk memanfaatkan kesempatan ekonomi yang dimunculkan oleh perkembangan perkebunan.

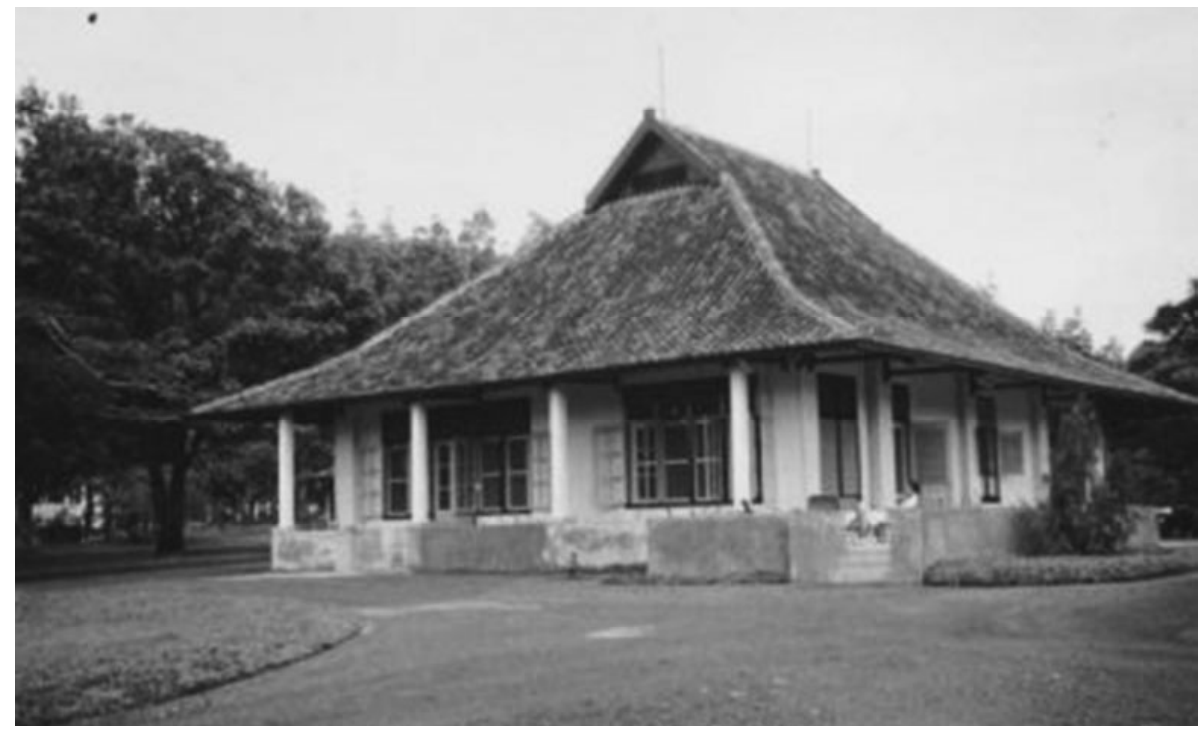

Gambar 9. Rumah dinas administrator perkebunan Tebenan di Onderafdeeling Banjoeasin en Koeboestrekken, 1938. (Sumber: kitlv.nl.) 
Keempat, masuknya perkebunan-perkebunan besar di Onderafdeeling Banjoeasin en Koeboestrekken yang banyak membangun jalan penghubung untuk keperluan transportasi hasil karetnya, memiliki dampak yang luas dan mendalam terhadap pola masyarakat tradisional, tidak saja bagi orang Melayu Banyuasin, tetapi juga bagi segi-segi kehidupan orang Kubu di di Onderafdeeling Banjoeasin en Koeboestrekken. Jalan Palembang-Betung yang mengarah ke barat ke Sekayu dan Muara Rupit yang sudah ada sebelumnya, kemudian dilanjutkan pembangunan menuju ke arah utara, Bajoeng Lentjir terus ke Jambi. Pembangunan jalan-jalan utama serta jalan-jalan marga yang melewati marga-marga Kubu ini telah membuka isolir orangorang Kubu dengan orang-orang Melayu di Onderafdeeling Banjoeasin en Koeboestrekken. Sementara, orang-orang Melayu sendiri juga mulai berani masuk lebih jauh ke daerah margamarga Kubu. Akibatnya, kehadiran perkebunan besar di Onderafdeeling Banjoeasin en Koeboestrekken mampu mengenalkan mereka pada cara baru teknologi dalam mengelola hutan, di mana hutan di masyarakat Kubu terutama yang ada di Marga Bajat, Toengkal Oeloe, Dawas, Batang Hari Leko mulai ditanami karet rakyat yang mereka usahakan, seperti karet merah atau balammerah, karet suntih atau balamsoentih, karet susu atau balampoean.

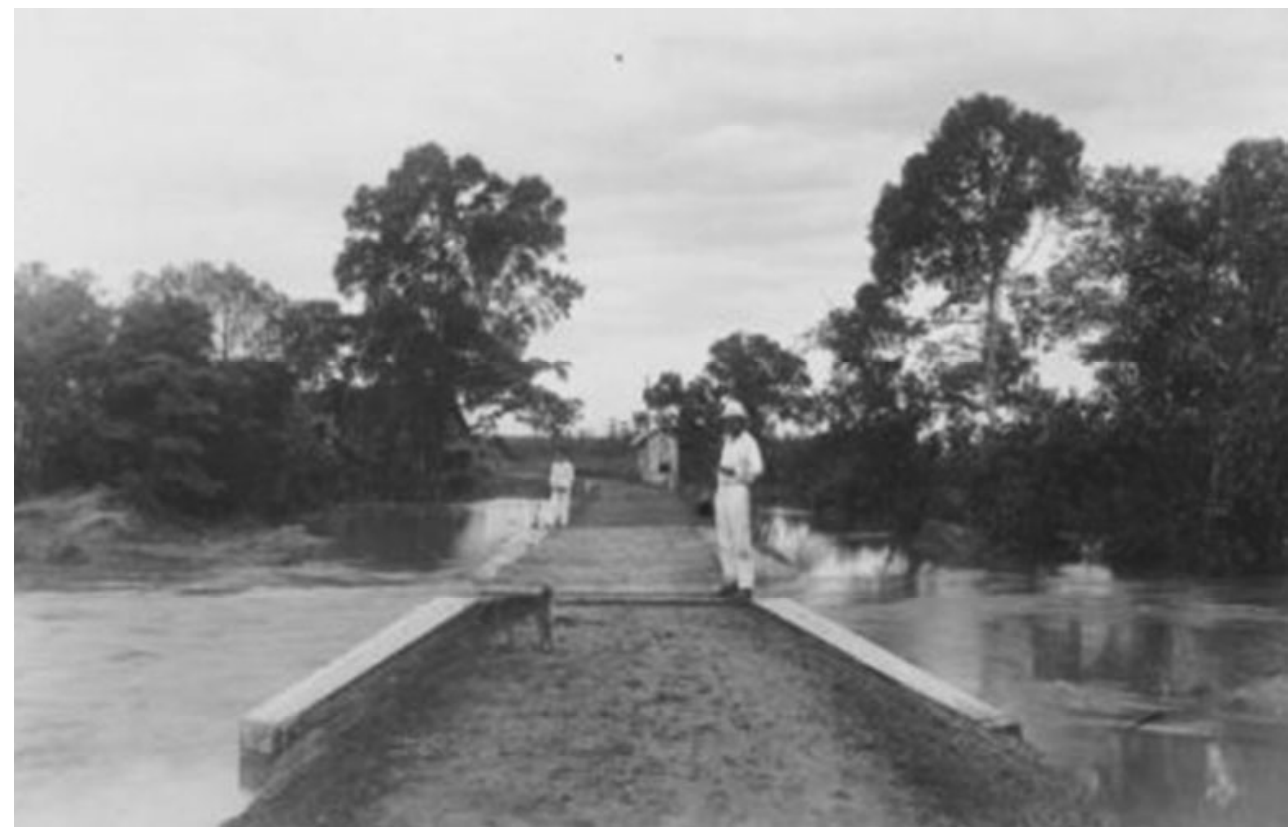

Gambar 10. Administratur Perusahaan Perkebunan Tebenan, A.J.G.Stevels, memeriksa pembangunan dam untuk irigasi sekaligus jembatan dan jalan yang dapat diperguna penduduk lokal pedusunan di aliran sungai Batanghari Leko, di Onderafdeeling Banjoeasin en Koeboestrekken, 1928. (Sumber: kitlv.nl)

Pengenalan mereka pada dunia perkebunan ini membawa pengaruh pada masyarakat Kubu di Onderafdeeling Banjoeasin en Koeboestrekken yang tampak sangat kuat dalam modernisai masyarakat kubu akibat adanya komersialisasi ekonominya. Dalam tulisan, Keereweer (1940: 357-396),kemudian mengilustrasikan dengan sangat menarik bahwa akibat adanya kesempatan dan kapitalisasi ekonomi dari pengaruh perkebunan besar di Onderafdeeling Banjoeasin en Koeboestrekken, orang-orang Kubu yang bersentuhan langsung telah mengadopsi kemajuan mereka dalam hal gaya hidup, misalnya mereka sudah mulai memakai jas hitam, bersarung rapi dan memakai sepatu, kemudian dalam selera makanan mereka telah mengadopsi 
makan nasi dengan lauk dari kaleng salmon dan minum limun. Yang tidak kalah penting dari hadirnya perkebunan besar di Onderafdeeling Banjoeasin en Koeboestrekken ini bagi masyarakat Kubu adalah mulai terciptanya asimilasi bertahap orang Kubu dengan penduduk Melayu akibat adanya perubahan orientasi pemikirannya karena mulai terbukanya daerah-daerah mereka dari pengaruh dunia luar. Masyarakat Kubu yang ada di Marga-marga Bajat, Toengkal Oeloe, Dawas dan Batang Hari Leko di Onderafdeeling Banjoeasin en Koeboestrekken bagian selatan, termasuk di Marga Kubu Lalan di Onderafdeeling Banjoeasin en Koeboestrekken bagian utara perlahan melakukan berbagai perubahan hidup sejalan dengan mulai masuknya mereka dalam agama Islam. Pada akhirnya, lewat kehadiran perkebunan besar ini, orang-orang Kubu di Onderafdeeling Banjoeasin en Koeboestrekken secara perlahan-lahan mampu mengindentifikasikan diri sebagai orang Melayu setelah mengawini penduduk Melayu, baik yang ada di marganya maupun di marga-marga lain di daerah Onderafdeeling Banjoeasin en Koeboestrekken tersebut.

\section{PENUTUP}

\section{a. Kesimpulan}

Bentang alam Onderafdeeling Banjoeasin en Koeboestrekken, walaupun dekat dengan pusat kuasa, ibukota Palembang menjadi daerah yang terisolir karena sulitnya perhubungan. Hampir semua wilayah di Onderafdeeling Banjoeasin en Koeboestrekken adalah daerah dataran rendah yang dihubungkan oleh sungai-sungai memanjang dan bercabang dari ilirnya di muara laut sampai masuk ke daerah uluan di pedalaman Onderafdeeling Banjoeasin en Koeboestrekken. Menariknya hampir semua daerah bagian utaranya sangat sulit berhubungan dengan ibukota Palembang karena sungai-sungai besar beserta anak sungainya tersebut tidak memiliki pertemuan dengan Sungai Musi. Secara kependudukan Onderafdeeling Banjoeasin en Koeboestrekken terdiri dari dua wilayah kultural yakni suku Melayu Banjoeasin dan masyarakat Kubu yang dianggap masih sangat "tradisional" berada pada wilayah utara atau di bagian ulu anak-anak sungai aliran sungai Air Banjoeasin.

Keberadaan perkebunan di Onderafdeeling Banjoeasin en Koeboestrekken masuk menjelang pertengahan abad ke-20. Ada dua perusahaan besar yang melakukan investasi besarbesaran perkebunan besar karet yakni, pertama, Rubber Ondernemingen Melania pada tahun 1909 di bawah bendera perusahaan-perusahaan Internasional Belgia, bernama perusahaan Sociente Financiere des Caoutchoues. Perkebunan Rubber Ondernemingen Melaniamelakukan penanaman dan usaha karet secara besar-besaran mulai dari ujung timur Marga Pangkalan Balai sampai ke ujung barat Marga Gasing. Perusahaan perkebunan, Rubber Ondernemingen Melania di Onderafdeeling Banjoeasin en Koeboestrekken ini berpusat di Musi Landas. Kedua, perkebunan Oud Wassenaar, N.V. Oliepalmen en rubber Mij. Perusahaan Perkebunan Karet dan kepala sawit Oud Wassenar membentang luas di daerah-daerah talang mulai bagian utara Batang Hari Leko, Marga Rantau Bayur, ke utaranya Marga Suak Tape, Marga Betung dan daerah Tebenan.

Hubungan pertalian perkebunan dan masyarakat di Onderafdeeling Banjoeasin en Koeboestrekken terasa dalam beberapa hal kemudian sebagai dampak turunan dari kehadiran 
onderneming asing ini. Pertama, kehadiran onderneming di Onderafdeeling Banjoeasin en Koeboestrekken, terlihat dari adanya perubahan posisi elit lokal, para pasirah, kerio, pejabat dewan marga lainnya. Kedua, hadirnya onderneming, perkebunan besar Eropa di Onderafdeeling Banjoeasin en Koeboestrekken, turut menciptakan "perbaikan" sarana dan prasana infrastruktur masyarakat di sana. Ketiga, insfrastruktur ini secara tidak langsung, mampu mendorong berkembangnya kegiatan ekonomi dan memberikan dampak yang luar biasa di dusun-dusun marga di Onderafdeeling Banjoeasin en Koeboestrekken. Keempat, masuknya perkebunanperkebunan besar di Onderafdeeling Banjoeasin en Koeboestrekken yang banyak membangun jalan penghubung untuk keperluan transportasi hasil karetnya, memiliki dampak yang luas dan mendalam terhadap pola masyarakat tradisional, tidak saja bagi orang Melayu Banyuasin, tetapi juga bagi segi-segi kehidupan orang Kubu di di Onderafdeeling Banjoeasin en Koeboestrekken. Akibatnya, kehadiran perkebunan besar di Onderafdeeling Banjoeasin en Koeboestrekken mampu mengenalkan mereka pada cara baru teknologi dalam mengelola hutan, di mana hutan di masyarakat Kubu terutama yang ada di Marga Bajat, Toengkal Oeloe, Dawas, Batang Hari Leko mulai ditanami karet rakyat yang mereka usahakan, seperti karet merah atau balammerah, karet suntih atau balamsoentih, karet susu atau balampoean. Yang tidak kalah penting dari hadirnya perkebunan besar di Onderafdeeling Banjoeasin en Koeboestrekken ini bagi masyarakat Kubu adalah mulai terciptanya asimilasi bertahap orang Kubu dengan penduduk Melayu akibat adanya perubahan orientasi pemikirannya karena mulai terbukanya daerah-daerah mereka dari pengaruh dunia luar.

\section{b. Saran}

Berdasarkan kesimpulan dalam tulisan ini, maka disarankan beberapa hal sebagai berikut:

Pertama, perlu adanya penelitian terus menerus mengenai sjarah ekonomi, sosial budaya, terutama yang berhubungan dengan perkebunan dalam mengungkap dampak positif kehadirannya, ditengah bermunculannya dampak negatai seperti sekarang ini, terutama dalam konflik lahan. Hal ini penting sebagai balance suatu kebijakan ekonomi, terutama di Sumatera Selatan.

Kedua, perkebunan perlu terus diingatkan, seperti halnya dalam perjalanan sejarahnya, untuk selalu membuat kebijakan yang pro rakyat dengan tatanan pengembangan ekonomi yang luas. Ketiga, masyarakat perlu diingatkan untuk selalu proaktif mengambil setiap peluang dari adanya kesempatan ekonomi baru yang ada disekitarnya. 


\section{DAFTAR PUSTAKA}

Bappeda Pemerintah Kabupaten Banyuasin. 2008. Rencana Pembangunan Jangka Panjang (RPJP) Daerah Kabupaten Banyuasin Tahun 2006-2025. Banyuasin: Pemkab Banyuasin.

Bappeda Pemerintah Kabupaten Banyuasin. 2014. Kabupaten Banyuasin dalam Angka Tahun 2014. Banyuasin: Pemkab Banyuasin.

Clemens, Adrian H. P. 1988. De bevolkingsrubbercultuur in Djambi en Palembang tijdenshet Interbellum. Scriptie Universiteit van Amsterdam.

Cramer, H. 1917. Het Verkeerswezen in Zuid-Sumatra. Weltreveden: Zuid-Sumatra Landbouw- en Nijverheids Vereeniging.

Day, Clive. 2009. The Policy and Administration of the Dutch in Java: 1904. London: The Macmillan Company. de Bruyn, Kops G. .F. 1919. Overzicht van Zuid-Sumatra. Amsterdam: Druk van J. H. De Bussy.

Gottschalk, Louis. 1986. Mengerti Sejarah. Terj. Nugroho Notosusanto. Jakarta: Universitas Indonesia Press.

Hasan, Hambali, dkk. 2007. Sejarah Rakyat dan Pemerintahan Kabupaten Banyuasin. Pangkalan Balai: Pemerintah Kabupaten Banyuasin.

Hasan, Hambali, dkk. Pola Penguasaan, Pemilikan dan Penggunaan Tanah Secara Tradisional Daerah Sumatera Selatan. Palembang: Depdikbud Propinsi Sumatera Selatan, 1991/1992.

Hoedt, Th. G.E. 1929. Indische Bergcultuur-ondernemingen in Zuid Sumatra. Wegeningen: H. Veenman \& Zonen.

Kartodirdjo, Sartono dan Djoko Suryo. 1991. Sejarah Perkebunan di Indonesia : Kajian Sosial-Ekonomi. Yogyakarta : Aditya Media

Keereweer, H. H. 1940. De Koeboes in de Onder-afdeeling Moesi Ilir en Koeboestrekken. Bijdragen tot de Taal-, Land-en Volkenkunde van Nederlandsch-Indie. 99 (3de): 357-396.

Lindayanti. 1994. Perkebunan Karet Rakyat Jambi 1920-1928: Aspek Sosial Ekonomi. Jakarta: Gramedia Pustaka Utama.

Memorie van Overgave Controlir C. Van de Velde tanggal 3 Desember 1918 No. 13.

Oktasari, Indah Ningtyas dan Agus Trilaksana. 2014. Perkebunan Kopi Rakyat di Jawa Timur. Jurnal Avatara. 2 (1) : 122-129.

O’Malley, William Joseph. 1988. Perkebunan 1830-1940: Ikhtisar. in Anne Booth, William J.O'Malley, dan Anna Wiedemann, Eds. Sejarah Ekonomi Indonesia. Terj. Jakarta: Penerbit LP3ES.

Peeters, Jeroen. 1997. Kaum Tuo-Kaum Mudo: Perubahan Religius di Palembang1821-1942. Jakarta: INIS.

Pranoto, Suhartono W. 2010. Teori dan Metodologi Sejarah. Yogyakarta: Graha Ilmu.

Purwanto, Bambang. Menelusuri Akar Ketimpangan dan Kesempatan Baru: Catatan tentang Sejarah Perkebunan Indonesia. dalam website sejarah.fib.ugm.ac.id, diunduh 8 Agustus 2015.

Purwanto, Bambang. 1993. From Dusun To The Market;Native Rubber Cultivation In Southern Sumatra, 1890-1940. Ph. D. Dissertation. School Of Oriental And African Studies, Oxford University. 
Ritzet, George. 2007. Teori Sosiologi Modern. Jakarta:Prenada Media Group

Staatblad nomor 93 Tahun 1906.

Suwirta, Andi. 2002. Buruh Perkebunan di Sumatera Timur: Sebuah Tinjauan Sejarah. Historia: Jurnal Pendidikan Sejarah. 5 (III): 19-36

Van Dongen dan L. F. Wesly. 1910. De Koeboes in De Onderafdeeling Koeboestreken Der Residentie Palembang. Bijdragen tot de Taal-, Land-en Volkenkunde van Nederlandsch-Indië, 63 (9): 177-336.

Van Hasselt, A. L. 1922. Volksbeschrijving van Midden Sumatra. Leiden: E. J. Brill.

Wellan, J. W. J., Zuid-Sumatra: Overzicht van de Gewesten Djambi, Palembang, de Lampoengsche Districten en Bengkoelen. Wegeningen: H. Veenman \& Zoon, 1932.

Zed, Mestika. 2002. Ekonomi Dualistis Palembang pada Periode Kolonial Akhir. dalam J. Thomas Lindblad. eds. Fondasi Historis Ekonomi Indonesia. Yogyakarta: Pustaka Pelajar.

Zed, Mestika. 2003.Kepialangan Politik dan Revolusi: Palembang 1900-1950. Jakarta: LP3ES. 